\title{
KEBERLAKUAN UU NO. 6 TAHUN 2014 TENTANG DESA DI BALI DALAM PERSPEKTIF SOSIOLOGI HUKUM*
}

\author{
Mulyanto $^{* *}$ \\ Bagian Hukum dan Masyarakat Fakultas Hukum Universitas Sebelas Maret, Surakarta \\ Jalan Ir. Sutami No. 36A, Kentingan, Jebres, Surakarta, Jawa Tengah 57126
}

\begin{abstract}
The objective of research to determine the validity of Act No. 6 of 2014 in Bali. The research method used sosiolegal. The results showed there was a conflict between the norms of Article 6 of the explanation of the obligation to choose one type of village. During this time, the system of village administration is double the traditional village (pakraman) and village office (administration) in Bali. Sociologically, society, academics, community leaders, Perbekel and Bendesa declare that Article 6 was not suitable to be applied in Bali. Main Assembly Pakraman (MUDP) proposed Bali get an exception.
\end{abstract}

Keywords: Act No. 6 of 2014, the traditional village, sociology of law.

\section{Intisari}

Tujuan penelitian untuk mengetahui keberlakuan UU No. 6 Tahun 2014 di Bali. Metode penelitian menggunakan sosiolegal. Hasil penelitian menunjukkan ada konflik norma (conflict of norm) antara Pasal 6 dengan Penjelasannya tentang kewajiban memilih salah satu jenis desa. Selama ini, sistem pemerintahan desa bersifat ganda antara desa adat (pakraman) dan desa dinas (administrasi) di Bali. Secara sosiologis, masyarakat Bali, akademisi, tokoh masyarakat, Perbekel maupun Bendesa menyatakan Pasal 6 tidak cocok diterapkan di Bali. Majelis Utama Desa Pakraman (MUDP) mengusulkan supaya Bali mendapatkan pengecualian.

Kata Kunci: UU No. 6 Tahun 2014, desa adat, sosiologi hukum.

\section{Pokok Muatan}

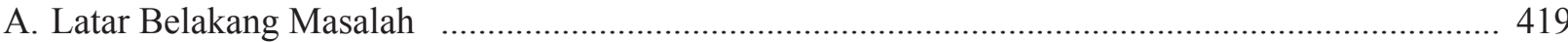

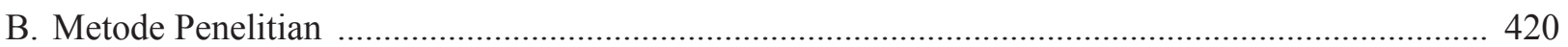

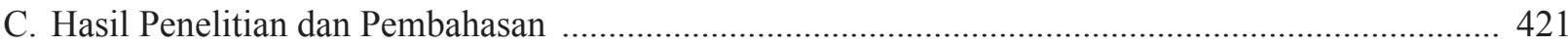

1. Keberlakuan UU No. 6 Tahun 2014 dari Aspek Yuridis, Sosiologis, dan Filosofis ................... 421

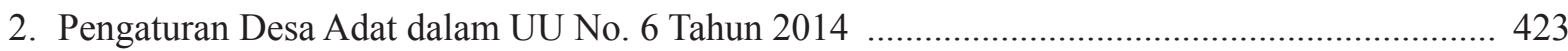

3. Konflik Norma (Conflict of Norm) Pasal 6 UU No. 6 Tahun 2014 ............................................ 425

4. Dilema Pilihan "Desa Adat (Pakraman)" vs "Desa Dinas" ......................................................... 427

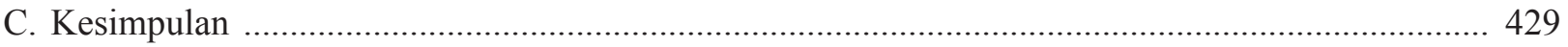

Penelitian Pendahuluan Disertasi Program Doktor Fakultas Hukum Universitas Gadjah Mada (UGM) Tahun 2015.

Alamat korespondensi: sheemoel@yahoo.com 


\section{A. Latar Belakang Masalah}

Sejak Negara Kesatuan Republik Indonesia berdiri, baru kali ini ada Undang-undang yang secara khusus mengatur tentang desa dan desa adat yang tertuang dalam UU No. 6 Tahun 2014 tentang Desa. Selama ini, pengaturan tentang desa selalu menjadi bagian dari UU Pemerintahan Daerah. ${ }^{1}$ Undang-Undang ini ini diharapkan dapat mempercepat pembangunan di Desa. Segala potensi di daerah dapat lebih diberdayakan untuk kesejahteraan masyarakat desa.

UU No. 6 Tahun 2014 disusun dengan semangat penerapan amanat Konstitusi, yaitu pengaturan masyarakat hukum adat sesuai dengan ketentuan Pasal 18B ayat (2) UUD $1945 .{ }^{2}$ Pengakuan kesatuan masyarakat hukum adat membawa konsekuensi: ${ }^{3}$ (1) pengakuan terhadap kesatuan masyarakat hukum adat sebagai subjek hukum; (2) pengakuan terhadap struktur dan tata pemerintahan adat; (3) pengakuan terhadap hukum adat; (4) pengakuan terhadap hak-hak atas harta benda adat termasuk hak ulayat.

Dengan konstruksi menggabungkan fungsi self-governing community dengan local self government, diharapkan kesatuan masyarakat hukum adat yang selama ini merupakan bagian dari wilayah Desa, ditata sedemikian rupa menjadi Desa dan Desa Adat. Pada dasarnya Desa dan Desa Adat melakukan tugas yang hampir sama. Perbedaannya hanya dalam pelaksanaan hak asal-usul, terutama menyangkut pelestarian sosial Desa Adat, pengaturan dan pengurusan wilayah adat, sidang perdamaian adat, pemeliharaan ketenteraman dan ketertiban bagi masyarakat hukum adat, serta pengaturan pemerintahan berdasarkan susunan asli.
Pada dasarnya kesatuan masyarakat hukum adat terbentuk berdasarkan tiga prinsip dasar, yaitu genealogis, teritorial, dan gabungan genealogis-teritorial. Adapun yang diatur dalam Undang-Undang No. 6 Tahun 2014 yakni kesatuan masyarakat hukum adat yang merupakan gabungan antara genealogis dan teritorial. Implementasi dari kesatuan masyarakat hukum adat tersebut telah ada dan hidup di wilayah Negara Kesatuan Republik Indonesia, seperti huta/nagori di Sumatera Utara, gampong di Aceh, nagari di Minangkabau, marga di Sumatera bagian selatan, tiuh atau pekon di Lampung, desa pakraman/desa adat di Bali, lembang di Toraja, banua dan wanua di Kalimantan, dan negeri di Maluku.

Salah satu contoh kemajemukan kesatuankesatuan masyarakat hukum adat yang berada dalam lingkungan hukum adat dan kukubannya, dapat diamati pada kesatuan-kesatuan masyarakat hukum adat yang ada di daerah Bali. ${ }^{4}$ Desa Pakraman sebagai kesatuan masyarakat hukum adat di Bali, yang dalam kerangka pandangan Van Vollenhoven ${ }^{5}$ merupakan salah satu dari 19 (sembilan belas) kukuban hukum atau lingkaran hukum (rechtskring).

Peraturan Daerah Propinsi Bali Nomor 3 Tahun 2001 tentang Desa Pakraman, sebagaimana diubah dengan Peraturan Daerah Provinsi Bali Nomor 3 Tahun 2003 Tentang Perubahan Atas Peraturan Daerah Propinsi Bali Nomor 3 Tahun 2001 tentang Desa Pakraman, mendefinisikan pengertian desa pakraman sebagai berikut:

Desa Pakraman adalah kesatuan masyarakat hukum adat di Propinsi Bali yang mempunyai satu kesatuan tradisi dan tata krama pergaulan

Dalam sejarah pengaturan Desa, telah ditetapkan beberapa kali UU Pemerintahan Desa mulai UU No. 22 Tahun 1948, UU No. 1 Tahun 1957, UU No. 18 Tahun 1965, UU No. 19 Tahun 1965, UU No. 5 Tahun 1974, UU No. 22 Tahun 1999 dan UU No. 32 Tahun 2004 Lihat Bagian Penjelasan UU No. 6 Tahun 2014.

Negara mengakui dan menghormati kesatuan-kesatuan masyarakat hukum adat serta hak-hak tradisionalnya sepanjang masih hidup dan sesuai dengan perkembangan masyarakat dan prinsip Negara Kesatuan Republik Indonesia, yang diatur dalam undang-undang.

I Made Subawa, 2003, Implikasi Yuridis Pengalihan Kekuasaan Membentuk Undang-Undang terhadap Sistem Ketatanegaraan Republik Indonesia Pasca Perubahan Undang-Undang Dasar 1945, Disertasi, Program Pascasarjana Universitas Airlangga, Surabaya, hlm. 1.

Gede Marhaendra Wija Atmaja, 2012, Politik Pluralisme Hukum dalam Pengakuan Kesatuan Masyarakat Hukum Adat dengan Peraturan Daerah, Disertasi, Program Doktor Ilmu Hukum Universitas Brawijaya, Malang, hlm. 197.

Soepomo, 2003, Bab-Bab tentang Hukum Adat, Pradnya Paramita, Jakarta, hlm. 49. Lihat juga B. Ter Haar Bzn, 1979, Asas-Asas dan Susunan Hukum Adat (Terj.K. Ng. Soebakti Poesponoto), Pradnya Paramita, Jakarta, hlm. 301-302. Lihat juga Soerjono Soekanto, 2010, Hukum Adat Indonesia, Raja Grafindo Persada, Jakarta, hlm. 19-20. 
hidup masyarakat umat Hindu secara turun temurun dalam ikatan Kahyangan Tiga atau Kahyangan Desa yang mempunyai wilayah tertentu dan harta kekayaan sendiri serta berhak mengurus rumah tangganya sendiri. ${ }^{6}$

Menurut I Ketut Sudantra ${ }^{7}$, Desa pakraman di Bali merupakan masyarakat hukum adat dengan ciri khusus berkaitan dengan landasan filosofis Hindu yang menjiwai kehidupan masyarakat hukum adat di Bali, yang dikenal dengan filosofi Tri Hita Karana. Secara literlijk berarti tiga (tri) penyebab (karana) kebahagiaan (hita) yaitu Ida Sanghyang Jagatkarana (Tuhan Sang Pencipta), bhuana (alam semesta) dan manusa (manusia). Tri Hita Karana merupakan faktor signifikan bagi terwujudnya hubungan yang harmonis antara manusia dengan manusia, manusia dengan alam dan manusia dengan Tuhannya. $^{8}$

Eksistensi Desa Pakraman sebagai Desa Adat di Bali akan terkena pengaruh dari lahirnya UU No. 6 Tahun 2014. Oleh karena itu, penelitian ini akan memotret implikasi keberlakuan UU No. 6 Tahun 2014 dengan menggunakan perspektif sosiologi hukum. ${ }^{9}$

Menurut Achmad $\mathrm{Ali}^{10}$, sosiologi hukum menekankan kajian pada law in action, hukum dalam kenyataannya, yang berarti berada di dunia sein dengan menggunakan pendekatan empiris yang bersifat deskriptif. Dalam teori sosiologi hukum bahwa hukum itu tidak netral dan tidak bebas nilai tetapi berkaitan erat dengan nilai-nilai sosial budaya masyarakat. ${ }^{11}$ Menurut Satjipto Rahardjo ${ }^{12}$, metode kerja sosiologi hukum memenuhi standar kerja metode keilmuan, yaitu: (1) membuat deskripsi mengenai objeknya, (2) membuat penjelasan (explanation), (3) mengungkapkan (revealing), dan (4) membuat prediksi.

Berdasarkan uraian latar belakang masalah di atas, maka perumusan masalahnya yakni, bagaimana implikasi keberlakuan UU No. 6 tahun 2014 terhadap eksistensi Desa Pakraman di Bali dalam perspektif sosiologi hukum?

\section{B. Metode Penelitian}

Dalam penelitian ini digunakan metode sosiolegal. Studi sosiolegal merupakan kajian terhadap hukum dengan menggunakan pendekatan ilmu hukum maupun ilmu sosial. ${ }^{13}$ Artinya mendekati masalah hukum sesuai dengan kenyataan yang hidup dalam kehidupan praktis. Adapun sifat penelitiannya deskriptif yang memberikan gambaran secara sistematis terhadap objek. ${ }^{14}$ Data yang dipergunakan dalam penelitian ini dapat dikelompokkan menjadi dua jenis yakni data primer dan data sekunder. Data primer yang langsung diperoleh dari Narasumber di lapangan yang terpilih (purposive sampling) yaitu: (1) Bp. I Nyoman Juni Antara, S.Pd. selaku Bendesa Adat Desa Pakraman Adeng, Banjar Dinar Adeng, Desa Tegaljadi, Kecamatan Marga, Kabupaten Tabanan; (2) Bp. I Wayan Kardana, selaku Perbekel Desa Luwus, Kecamatan Mengwi, Kabupaten Badung; (3) Bp. I Ketut Widia sebagai Tokoh Masyarakat Adat Bali; (4) Bp. Ida Bagus Geger dari Bagian Hukum Pemkab Badung; dan (5) Wayan P. Windia, Guru Besar Hukum Adat Bali Fakultas Hukum Universitas Udayana.

Pasal 1 angka 4 Peraturan Daerah Bali No. 3 Tahun 2001 (Lembaran Daerah Provinsi Bali Tahun 2001 Nomor 29, Tambahan Lembaran Daerah Provinsi Bali Nomor 3).

I Ketut Sudantra, 2007, Pelaksanaan Fungsi Hakim Perdamaian Desa dalam Kondisi Dualisme Pemerintahan Desa di Bali, Tesis Program Pasca Sarjana Universitas Udayana, Denpasar, hlm. 53.

Sudjito, 2014, Ilmu Hukum Holistik: Studi untuk Memahami Kompleksitas dan Pengaturan Pengelolaan Irigasi, Gadjah Mada University Press, Yogyakarta, hlm. 12.

Karakteristik kajian sosiologi hukum yakni kajian yang memfokuskan kajiannya pada realitas dan perilaku hukum, atau mengkaji hukum dalam wujudnya sebagai das sein (kenyataan). Musakkir, "Kajian Sosiologi Hukum terhadap Penerapan Prinsip Keadilan Restoratif dalam Penyelesaian Perkara Pidana”, Jurnal Ilmu Hukum Amanna Gappa, Vol. 19, No. 3, September 2011, hlm. 208.

10 Achmad Ali, 1998, Menjelajahi Kajian Empiris terhadap Hukum, Yasrif Watampone, Jakarta, hlm. 11.

11 Sulastriyono, "Kajian Pembangunan Hukum Sumber Daya Air Sungai dalam Pespektif Sosiologi Hukum", Mimbar Hukum, Vol. 20, No. 1, Februari 2008, hlm. 65.

Satjipto Rahardjo, 2010, Sosiologi Hukum: Perkembangan Metode dan Pilihan Masalah, Genta Publishing, Yogyakarta, hlm. 58.

13 Sulistyowati Irianto dan Shidarta, 2009, Metode Penelitian Hukum: Konstelasi dan Refleksi, Yayasan Obor Indonesia, Jakarta, hlm. 174.

14 Bambang Sunggono, 2006, Metodologi Penelitian Hukum, Raja Grafindo Persada, Jakarta, hlm. 35. 
Adapun data sekunder merupakan data yang diperoleh dari hasil penelaahan literatur (bahan pustaka) yang berkaitan dengan materi penelitian. ${ }^{15}$ Data sekunder adalah data yang sudah tersedia. ${ }^{16}$ Dari sudut kekuatan mengikatnya ada tiga bahan hukum meliputi: ${ }^{17}$ (a) bahan hukum primer yang memiliki kekuatan mengikat, yakni UUD NRI Tahun 1945 dan UU No. 6 Tahun 2014 tentang Desa; (b) bahan hukum sekunder yang memberikan penjelasan mengenai bahan hukum primer meliputi berbagai buku, artikel, jurnal, makalah, laporan penelitian, data dari internet yang berkaitan dengan objek penelitian; dan (c) bahan hukum tersier yang memberikan petunjuk maupun penjelasan terhadap bahan hukum primer dan sekunder seperti Kamus.

Alat pengumpulan data dalam penelitian ini ada dua yakni studi pustaka (literature review) dan wawancara (interview). Studi pustaka berguna untuk mengumpulkan literatur-literatur yang relevan dengan topik penelitian. ${ }^{18}$ Pedoman wawancara sebagai acuan wawancara terstruktur (structured interview) maupun tidak terstruktur (unstructured interview) bagi peneliti yang akan menanyakan informasi dari narasumber. ${ }^{19}$ Guna mendapatkan keterangan dan masukan dari informan dilakukan melalui wawancara mendalam (depth interview) ${ }^{20}$

Jalannya Penelitian melalui 3 (tiga) tahapan yakni Pertama, melakukan penelitian kepustakaan (library research). Kedua, melakukan penelitian lapangan (field research). Ketiga, melakukan analisis data dan menyusun laporan hasil penelitian. Analisis data dilakukan secara kualitatif, mengingat data yang terkumpul merupakan data kualitatif ${ }^{21}$ dengan menggunakan metode interpretasi hermeneutic. Penafsiran hermeneutika hukum ${ }^{22}$, yaitu interpretasi terhadap teks-teks hukum tidak sematamata dari aspek legal formal berdasar bunyi teks, tetapi juga dari faktor yang melatar belakangi, aspek sosio-politik dan kulturalnya. Penelitian ini menggunakan logika deduktif yakni berangkat dari kerangka teori lalu dikorelasikan dengan kenyataan objektif. Dari hasil analisis akan diperoleh jawaban permasalahan yang telah dirumuskan sekaligus mengambil kesimpulan.

\section{Hasil Penelitian dan Pembahasan}

1. Keberlakuan UU No. 6 Tahun 2014 dari Aspek Yuridis, Sosiologis, dan Filosofis

Suatu Undang-Undang mempunyai persyaratan untuk dapat berlaku atau untuk mempunyai kekuatan berlaku. Ada 3 (tiga) macam kekuatan berlaku, yaitu kekuatan berlaku yuridis, sosiologis dan filosofis. ${ }^{23}$ Pertama, kekuatan berlaku yuridis (Juristische Geltung). Undang-undang mempunyai kekuatan berlaku yuridis apabila persyaratan formal terbentuknya undang-undang terpenuhi. Kedua, kekuatan berlaku sosiologis (Soziologische Geltung) dengan teori kekuasaan (Machtstheorie) apabila dipaksakan berlakunya oleh penguasa dan teori pengakuan (Anerkennungstheorie) apabila diterima dan diakui oleh warga masyarakat. Ketiga, kekuatan berlaku filosofis (Filosofische Geltung). Hukum mempunyai kekuatan berlaku filosofis apabila kaedah hukum tersebut sesuai dengan cita-cita hukum (Rechtsidee), sebagai nilai positif tertinggi, yaitu Pancasila

Berikut dipaparkan kekuatan berlaku yuridis UU No. 6 Tahun 2014. Pertama, kesatuan masyarakat hukum adat diamanatkan dalam Pasal 18B ayat (2) Undang-Undang Dasar 1945 adanya

\footnotetext{
15 Mukti Fajar Nur Dewata dan Yulianto Achmad, 2010, Dualisme Penelitian Hukum Normatif dan Empiris, Pustaka Pelajar, Yogyakarta, hlm. 156.

16 Maria S.W. Sumardjono, 2006, Bahan Kuliah Metodologi Penelitian Hukum, Universitas Gadjah Mada, Yogyakarta, hlm. 13.

7 Soerjono Soekanto, 1986, Pengantar Penelitian Hukum, Penerbit Universitas Indonesia (UI Press), Jakarta, hlm. 51-52.

18 John W Creswell, 2009, Research Design: Qualitative, Quantitative and Mixed Methods Approaches, Third Edition, Sage Publication Inc., California, hlm. 25.

William L. Neuman, 2006, Social Research Methods, Qualitative and Quantitative Approaches, Sixth Edition, Pearson, USA, hlm. 46.

20 Sabian Utsman, 2010, Dasar-Dasar Sosiologi Hukum: Dilengkapi Proposal Penelitian Hukum (Legal Research), Pustaka Pelajar, Yogyakarta, hlm. 384 .

Lexy J. Moleong, 2005, Metodologi Penelitian Kualitatif, Remaja Rosdakarya, Bandung, hlm. 153.

22 Jazim Hamidi, 2011, Hermeneutika Hukum: Sejarah, Filasafat dan Metode Tafsir, UB Press, Malang, hlm. 119.

23 Sudikno Mertokusumo, 2005, Mengenal Hukum (Suatu Pengantar), Edisi Kelima Cetakan Kedua, Liberty, Yogyakarta, hlm. 94-95.
} 
kesatuan masyarakat hukum adat. Kemudian dalam penjelasan umum Undang-Undang No. 32 Tahun 2004 tentang Pemerintahan Daerah dijelaskan “[....], maka otonomi Desa akan diberikan kesempatan untuk tumbuh dan berkembang mengikuti perkembangan dari Desa itu sendiri [...]". Hal ini berarti bahwa Desa sebagai susunan pemerintahan terendah di Indonesia mempunyai identitas dan entitas yang berbeda dan perlu di atur tersendiri dalam bentuk Undang-Undang.

Kedua, pengakuan dan penghormatan negara terhadap Desa dalam Konstitusi. Dalam penjelasan Pasal 18 disebutkan bahwa: Dalam teritori Negara Indonesia terdapat lebih kurang 250 zelfbesturende landchappen dan volksgetneenschappen, seperti Desa di Jawa dan Bali, negeri di Minangkabau, dusun dan marga di Palembang dan sebagainya. Daerahdaerah itu mempunyai susunan asli, dan dapat dianggap sebagai daerah yang bersifat istimewa. Artinya, NKRI harus mengakui keberadaan DesaDesa di Indonesia yang bersifat beragam. Konsep zelfbesturende landchappen identik dengan Desa otonom (local self government) atau disebut Desa Praja yang kemudian dikenal dalam UU Nomor 19 Tahun 1965, yakni Desa sebagai kesatuan masyarakat hukum yang berhak dan berwenang mengatur dan mengurus rumah tangganya sendiri. Sedangkan konsep volksgetneenschappen identik dengan kesatuan masyarakat hukum adat atau menurut orang Bali disebut dengan "Desa adat" atau self governing community. Zelfbesturende landschappen akan mengikuti asas desentralisasi (pemberian) dan volksgetneenschappen akan mengikuti asas rekognisi/pengakuan (bawaan).

Ketiga, penyerahan urusan/kewenangan dari kabupaten/kota kepada Desa sebenarnya tidak dikenal dalam teori desentralisasi. Jika UU Desa disusun terpisah dari UU Pemda, hal ini akan semakin mempertegas amanat dan makna Pasal 18 UUD 1945, sekaligus akan memperjelas posisi (kedudukan) dan kewenangan Desa atau memperjelas makna otonomi Desa. Implementasi pengakuan terhadap keanekaragaman otonomi desa yakni: Pertama, pemerintah desa tidak harus menggunakan nama desa. Diperbolehkan mempergunakan nama menurut adat istiadat seperti dusun, marga, nagari, meunasah, gampong, negorij dan lain sebagainya. Kedua, pengakuan terhadap otonomi asli. ${ }^{24}$ Van Vollenhoven berpendapat bahwa otonomi mencakup aktivitas-aktivitas (catur praja) seperti pembentukan peraturan perundangundangan sendiri (zelfwetgeving), melaksanakan sendiri (zelffuitvoering), melakukan peradilan sendiri (zelfrechtspraak), dan melakukan tugas kepolisian sendiri (zelf-politie). ${ }^{25}$

Selanjutnya dari aspek kekuatan berlaku sosiologis UU No. 6 Tahun 2014 dapat dideskripsikan sebagai berikut. Pertama, secara sosiologis, untuk menciptakan masyarakat adil dan makmur yang diamanatkan dalam Pembukaan UIUD 1945, bangsa Indonesia harus memulai paradigma pembangunan dari Desa karena sebagian besar penduduk Indonesia tinggal di Desa. Kedua, pengaturan otonomi Desa dimaksudkan untuk memperbaiki kerusakan-kerusakan sosial, budaya ekonomi dan politik Desa. "Otonomi Desa" hendak memulihkan basis penghidupan masyarakat Desa, dan secara sosiologis hendak memperkuat Desa sebagai entitas masyarakat paguyuban yang kuat dan mandiri.

Secara sosiologis, meskipun secara eksplisit istilah Desa hilang dalam UUD 1945 amandemen ke-2, tetapi klausul "Negara mengakui dan menghormati kesatuan-kesatuan masyarakat hukum adat beserta hak-hak tradisionalnya [...]" berarti mengharuskan negara melakukan rekognisi terhadap kesatuan-kesatuan masyarakat hukum adat, yang di dalamnya mencakup Desa, nagari, mukim, huta, sosor, kampung, marga, negeri, parangiu, pakraman, lembang dan seterusnya. UU No. 22 Tahun 1999 dan UU No. 32 Tahun 2004 telah memberikan pengakuan itu dan secara

\footnotetext{
24 Bagir Manan, 2001, Menyongsong Fajar Otonomi Daerah, Pusat Studi Hukum Fakultas Hukum UII, Yogyakarta, hlm. 12.

25 Dewan Perwakilan Daerah Republik Indonesia, 2009, Naskah Akademik Rancangan Undang-Undang tentang Perlindungan Masyarakat Adat, Dewan Perwakilan Daerah Republik Indonesia, Jakarta, hlm. 60.
} 
nasional melakukan penyebutan Desa (atau dengan nama lainnya). Pengakuan diberikan kepada eksistensi Desa (atau nama lain) beserta hak-hak tradisionalnya. ${ }^{26}$

Terakhir, dari aspek kekuatan berlaku filosofis UU No. 6 Tahun 2014. Pertama, secara filosofis, sebelum tata pemerintahan di atasnya ada, Desa itu lebih dulu ada. Maka, sebaiknya Desa harus menjadi landasan dari tata pengaturan pemerintahan dan menjadi ujung tombak dalam setiap penyelenggaraan urusan pemerintahan, pembangunan dan kemasyarakatan. Kedua, bahwa bangunan hukum Desa merupakan fundamen bagi tatanegara Indonesia. Artinya bahwa bangsa dan negara sebenarnya terletak di Desa, maka pengaturan Desa dalam Undang-Undang menjadi urgen. Ketiga, Undang-Undang pemerintahan Desa merupakan instrumen untuk membangun visi menuju kehidupan baru Desa yang mandiri, demokratis dan sejahtera. Dengan demikian, inisiatif lokal yang kuat merupakan fondasi lokal bagi kemandirian Desa.

\section{Pengaturan Desa Adat dalam UU No. 6} Tahun 2014

Dalam Bab I Ketentuan Umum Pasal 1 angka 1, didefinisikan pengertian desa adalah desa dan desa adat atau yang disebut dengan nama lain, selanjutnya disebut Desa adalah Kesatuan masyarakat hukum yang memiliki batas-batas wilayah yang berwenang untuk mengatur dan mengurus urusan pemerintahan, kepentingan masyarakat setempat berdasarkan prakarsa masyarakat, hak asal-usul, dan/atau hak tradisional yang diakui dan dihormati dalam sistem Pemerintahan NKRI. Hal ini berarti bahwa secara terminologi desa terdiri dari 2 (dua), yakni desa dan desa adat.

Desa adat merupakan warisan organisasi kepemerintahan masyarakat lokal yang dipelihara secara turun-temurun yang tetap diakui dan diperjuangkan oleh pemimpin dan masyarakat Desa Adat untuk mengembangkan kesejahteraan dan identitas sosial budaya lokal. Desa Adat memiliki hak asal usul yang lebih dominan sebagai komunitas asli di tengah masyarakat. Desa Adat sebagai kesatuan masyarakat hukum adat yang secara historis mempunyai batas wilayah dan identitas budaya yang terbentuk atas dasar teritorial yang berwenang mengatur dan mengurus kepentingan masyarakat Desa berdasarkan hak asal usul.

UU No. 6 Tahun 2014 sudah mengatur desa sesuai dengan UUD 1945 dengan menempatkan Desa berkedudukan di wilayah Kabupaten/Kota, yang diakui dan dihormati dalam Sistem Pemerintahan Negara Kesatuan Republik Indonesia. Tujuan diberlakukannya UU No. 6 Tahun 2014 antara lain: ${ }^{27}$ (1) memberikan pengakuan dan penghormatan atas Desa yang sudah ada dengan keberagamannya sebelum dan sesudah terbentuknya NKRI; (2) melestarikan dan memajukan adat, tradisi, dan budaya masyarakat Desa; dan (3) memperkuat masyarakat Desa sebagai subjek pembangunan.

Salah satu kemajuan UU No. 6 Tahun 2014 yakni menganut asas rekognisi yakni pengakuan terhadap hak asal-usul. Asas ini berbeda dengan asas otonomi daerah (dekonsentrasi, desentralisasi dan tugas pembantuan). Kalau asas desentralisasi di dasarkan pada prinsip penyerahan wewenang dari pemerintah kepada daerah otonom, maka asas rekognisi merupakan pengakuan dan penghormatan negara terhadap kesatuan-kesatuan hukum adat beserta hak-hak tradisionilnya (otonomi komunitas). A.A.G.N. Ari Dwipayana dan Sutoro Eko ${ }^{28}$ menyatakan asas rekognisi secara historis memiliki landasan yang kuat dari dulu hingga sekarang. Desa merupakan bentuk pemerintahan komunitas (self governing community) yakni komunitas yang menjalankan fungsi-fungsi pemerintahan tradisionil

\footnotetext{
26 H. Ateng Syafrudin dan Suprin Na'a, 2010, Republik Desa: Pergulatan Hukum Tradisional dan Hukum Modern dalam Desain Otonomi Desa, Alumni, Bandung, hlm. 43-44.

27 Selengkapnya lihat Pasal 4 Undang-Undang Nomor 6 Tahun 2014 tentang Desa (Lembaran Negara Republik Indonesia Tahun 2014 Nomor 7, Tambahan Lembaran Negara Republik Indonesia Nomor 5495).

28 A.A.G.N. Ari Dwipayana dan Sutoro Eko, "Pokok-Pokok Pikiran Untuk Penyempurnaan UU No. 32 Tahun 2004 Khusus Pengaturan tentang Desa", http://desentralisasi.org/makalah/Desa/AAGNAri Dwipayana SutoroEko PokokPikiranPengaturanDesa.pdf, diakses 20 April 2015.
} 
yang di dasarkan pada adat setempat dan kearifan lokal.

Dari XVI Bab dan 122 Pasal dalam UU No. 6 Tahun 2014, hanya 1 Bab Ketentuan Khusus Desa Adat dengan 16 Pasal. Bab XIII Ketentuan Khusus Desa Adat terdiri dari 4 bagaian yakni Bagian I Penataan Desa Adat (Pasal 96-102), Bagian II Kewenangan Desa Adat (Pasal 103-106), Bagian III Pemerintahan Desa Adat (Pasal 107-109), dan Bagian IV Peraturan Desa Adat (Pasal 110-111).

Pasal 96 UU No. 6 Tahun 2014 mengamanatkan Pemerintah, Pemerintah Daerah Provinsi, dan Pemerintah Kabupaten/Kota untuk melakukan penataan kesatuan masyarakat hukum adat dan ditetapkan menjadi Desa Adat. Penetapan Desa Adat dapat dilakukan apabila memenuhi persyaratan: (a) kesatuan masyarakat hukum adat beserta hak tradisionalnya secara nyata masih hidup, baik yang bersifat teritorial, genealogis, maupun yang bersifat fungsional; (b) kesatuan masyarakat hukum adat beserta hak tradisionalnya dipandang sesuai dengan perkembangan masyarakat; dan (c) kesatuan masyarakat hukum adat beserta hak tradisionalnya sesuai dengan prinsip Negara Kesatuan Republik Indonesia.

Kesatuan masyarakat hukum adat beserta hak tradisionalnya yang masih hidup harus memiliki wilayah dan paling kurang memenuhi salah satu atau gabungan unsur adanya: (a) masyarakat yang warganya memiliki perasaan bersama dalam kelompok; (b) pranata pemerintahan adat; (c) harta kekayaan dan/atau benda adat; dan/atau (d) perangkat norma hukum adat. Norma hukum adat di Bali, di Desa Pakraman disebut dengan awig-awig. ${ }^{29}$

Kesatuan masyarakat hukum adat beserta hak tradisionalnya dipandang sesuai dengan perkembangan masyarakat apabila: (a) keberadaannya telah diakui berdasarkan undang-undang yang berlaku baik undang-undang yang bersifat umum maupun bersifat sektoral; dan (b) substansi hak tradisional tersebut diakui dan dihormati oleh warga kesatuan masyarakat yang bersangkutan dan masyarakat yang lebih luas serta tidak bertentangan dengan hak asasi manusia.

Suatu kesatuan masyarakat hukum adat beserta hak tradisionalnya sesuai dengan prinsip NKRI apabila kesatuan masyarakat hukum adat tersebut tidak mengganggu keberadaan NKRI sebagai sebuah kesatuan politik dan kesatuan hukum yang tidak mengancam kedaulatan dan integritas NKRI; dan substansi norma hukum adatnya sesuai dan tidak bertentangan dengan ketentuan peraturan perundang-undangan.

Penetapan desa adat dilakukan dengan Peraturan Daerah Kabupaten/Kota. ${ }^{30}$ Pembentukan Desa Adat setelah penetapan Desa Adat dilakukan dengan memperhatikan faktor penyelenggaraan Pemerintahan Desa, pelaksanaan Pembangunan Desa, pembinaan kemasyarakatan Desa, serta pemberdayaan masyarakat Desa dan sarana prasarana pendukung. Pada dasarnya melalui UU No. 6 Tahun 2014 memungkinkan dilakukan Penggabungan Desa Adat atas prakarsa dan kesepakatan antar-Desa Adat dengan difasilitasi dari Pemerintah Daerah.

Dari aspek Status Desa, terdapat beberapa pilihan desa dapat diubah menjadi Desa Adat, kelurahan dapat diubah menjadi Desa Adat, Desa Adat dapat diubah menjadi Desa, dan Desa Adat dapat diubah menjadi kelurahan berdasarkan prakarsa masyarakat yang bersangkutan melalui Musyawarah Desa dan disetujui oleh Pemerintah Daerah Kabupaten/Kota. Dalam hal Desa diubah menjadi Desa Adat, kekayaan Desa beralih status menjadi kekayaan Desa Adat, dalam hal kelurahan berubah menjadi Desa Adat, kekayaan kelurahan beralih status menjadi kekayaan Desa Adat, dalam hal Desa Adat berubah menjadi Desa, kekayaan Desa Adat beralih status menjadi kekayaan Desa, dan dalam hal Desa Adat berubah menjadi kelurahan, kekayaan Desa Adat beralih status 
menjadi kekayaan Pemerintah Daerah Kabupaten/ Kota.

Kewenangan Desa Adat berdasarkan hak asal usul meliputi ${ }^{31}$ : (a) pengaturan dan pelaksanaan pemerintahan berdasarkan susunan asli; (b) pengaturan dan pengurusan ulayat atau wilayah adat; (c) pelestarian nilai sosial budaya Desa Adat; (d) penyelesaian sengketa adat berdasarkan hukum adat yang berlaku di Desa Adat dalam wilayah yang selaras dengan prinsip hak asasi manusia dengan mengutamakan penyelesaian secara musyawarah; (e) penyelenggaraan sidang perdamaian peradilan Desa Adat sesuai dengan ketentuan peraturan perundang-undangan; (f) pemeliharaan ketenteraman dan ketertiban masyarakat Desa Adat berdasarkan hukum adat yang berlaku di Desa Adat; dan (g) pengembangan kehidupan hukum adat sesuai dengan kondisi sosial budaya masyarakat Desa Adat.

Pelaksanaan kewenangan berdasarkan hak asal usul dan kewenangan berskala lokal Desa Adat diatur dan diurus oleh Desa Adat dengan memperhatikan prinsip keberagaman. Selain itu, desa adat diberi kewenangan yang bersifat penugasan dari Pemerintahn dan Pemerintah Daerah. Penugasan dari Pemerintah dan/atau Pemerintah Daerah kepada Desa Adat meliputi penyelenggaraan Pemerintahan Desa Adat, pelaksanaan Pembangunan Desa Adat, pembinaan kemasyarakatan Desa Adat, dan pemberdayaan masyarakat Desa Adat yang disertai dengan pembiayaan.

Pengaturan dan penyelenggaraan Pemerintahan Desa Adat ${ }^{32}$ dilaksanakan sesuai dengan hak asal usul dan hukum adat yang berlaku di Desa Adat yang masih hidup serta sesuai dengan perkembangan masyarakat dan tidak bertentangan dengan asas penyelenggaraan Pemerintahan Desa Adat dalam prinsip Negara Kesatuan Republik Indonesia. Pemerintahan Desa Adat menyelenggarakan fungsi permusyawaratan dan Musyawarah Desa Adat sesuai dengan susunan asli Desa Adat atau dibentuk baru sesuai dengan prakarsa masyarakat Desa Adat. Khusus untuk Susunan kelembagaan, pengisian jabatan, dan masa jabatan Kepala Desa Adat berdasarkan hukum adat ditetapkan dalam peraturan daerah Provinsi. Terkait Peraturan Desa Adat, pada dasarnya Peraturan Desa Adat disesuaikan dengan hukum adat dan norma adat istiadat yang berlaku di Desa Adat sepanjang tidak bertentangan dengan ketentuan peraturan perundang-undangan.

\section{Konflik Norma (Conflict of Norm) Pasal 6 UU No. 6 Tahun 2014 \\ UU No. 6 Tahun 2014 diundangkan di} Jakarta pada tanggal 15 Januari 2014 yang memiliki yurisdiksi di seluruh Indonesia. Meskipun semangat yang dihadirkan UU No. 6 Tahun 2014 dalam rangka mengimplementasikan amanah Konstitusi khususnya Pasal 18B ayat (2) UUD 1945, namun menimbulkan permasalahan tersendiri di Bali. Sumber masalah utama yakni ketidakkonsistenan dan ketidakjelasan Pasal 6 UU No. 6 tahun 2014 yang memerintahkan untuk memilih salah satu jenis desa. Padahal, secara sosiologis di Bali terdapat sistem pemerintahan desa yang bersifat ganda yang unik, tidak ada duanya di Indonesia dan terbukti mampu melindungi desa adat (pakraman) dan desa dinas secara berimbang (harmonis) sejak beradaabad hingga sekarang. ${ }^{34}$

Pasal 6 ayat (1) menyatakan bahwa "Desa terdiri atas Desa dan Desa Adat". Ayat (2): "Penyebutan Desa atau Desa Adat sebagaimana

31 Pasal 103 Undang-Undang Nomor 6 Tahun 2014 tentang Desa (Lembaran Negara Republik Indonesia Tahun 2014 Nomor 7 , Tambahan Lembaran Negara Republik Indonesia Nomor 5495).

32 Pasal 107 dan 108 Undang-Undang Nomor 6 Tahun 2014 tentang Desa (Lembaran Negara Republik Indonesia Tahun 2014 Nomor 7 , Tambahan Lembaran Negara Republik Indonesia Nomor 5495).

33 Wawancara dengan Bapak Ida Bagus Geger dari Bagian Hukum Pemerintah Kabupaten Badung Provinsi Bali pada hari Selasa 26 Mei 2015 bertempat di ruangan Sub Bag Perda dan Sub Bag Otda Kabupaten Badung. Beliau mengatakan, "Tidak satupun ketentuan sepanjang pengaturan desa dan desa adat di dalam UU Desa yang mengharuskan desa adat diubah menjadi desa atau sebaliknya, kecuali penjelasan pasal 6, Jadi ada semacam ketidakkonsistenan antara pengaturan Pasal 6 dan penjelasannya. Padahal implementasi di lapangan menimbulkan efek yang besar".

34 I Gde Parimartha, 2013, Silang Pandang Desa Adat dan Desa Dinas di Bali, Udayana University Press, Denpasar, hlm. 21. 
dimaksud pada ayat (1) disesuaikan dengan penyebutan yang berlaku di daerah setempat". Dalam penjelasan Pasal 6 dinyatakan bahwa: "Ketentuan ini mencegah terjadinya tumpang tindih wilayah, kewenangan, duplikasi kelembagaan antara Desa dan Desa Adat dalam 1 (satu) wilayah maka dalam 1 (satu) wilayah hanya terdapat Desa atau Desa Adat. Untuk yang sudah terjadi tumpang tindih Antara Desa dan Desa Adat dalam 1 (satu) wilayah, harus dipilih salah satu jenis Desa sesuai dengan ketentuan Undang-Undang ini”.

\section{Tabel 1. Konflik Norma}

\begin{tabular}{|c|c|}
\hline 14 menentukan bahn & $\begin{array}{l}6 \text { Tahun } 2014 \text {, menyatakan } \\
\text { bahwa dalam satu wilayah } \\
\text { hanya terdapat desa atau } \\
\text { desa adat. }\end{array}$ \\
\hline ra UU No. 6 Tahun 20 & $\begin{array}{l}\text { Penjelasan pasal } 6 \\
\text { meniadakan salah satu } \\
\text { diantara kedua desa yang } \\
\text { diakui ada oleh Pasal } 6 \\
\text { (integrasi). }\end{array}$ \\
\hline
\end{tabular}

Sumber: Disarikan dari Bagian Hukum Pemkab. Badung, tanggal 26 Mei 2015.

Apabila dikaji dari aspek legal drafting nyata adanya ketidakkonsistenan antara norma dalam Pasal dan Penjelasan. Penggunaan kata "dan" mengandung makna sebagai rincian komulatif, sehingga tidak dimaknai untuk memilih Desa atau Desa Adat (alternatif). Penjelasan Pasal 6 UU Desa melanggar teknik penyusunan peraturan perundangundangan, khususnya dalam perumusan penjelasan, yakni melanggar ketentuan Angka 176, 177, dan 178 Lampiran II UU No. 12 tahun 2011 Tentang Pembentukan Peraturan Perundang-undangan.

Angka 176 Lampiran II UU No. 12 tahun 2011 menyatakan bahwa Penjelasan berfungsi sebagai tafsir resmi pembentuk Peraturan Perundang-undangan atas norma tertentu dalam batang tubuh. Oleh karena itu, penjelasan hanya memuat uraian terhadap kata, frasa, kalimat atau padanan kata/istilah asing dalam norma yang dapat disertai dengan contoh. Penjelasan sebagai sarana untuk memperjelas norma dalam batang tubuh tidak boleh mengakibatkan terjadinya ketidakjelasan dari norma yang dimaksud. Selanjutnya Angka 177 Lampiran II UU No. 12 tahun 2011 mengatur Penjelasan tidak dapat digunakan sebagai dasar hukum untuk membuat peraturan lebih lanjut dan tidak boleh mencantumkan rumusan yang berisi norma. Terakhir, Angka 178 Lampiran II UU No. 12 tahun 2011 mengatur Penjelasan tidak menggunakan rumusan yang isinya memuat perubahan terselubung terhadap ketentuan Peraturan Perundang-undangan.

Dari perspektif yuridis, Penjelasan terhadap Pasal 6 UUNo. 6 Tahun 2014, tidak dapat digunakan sebagai dasar hukum untuk membuat peraturan lebih lanjut, dalam hal ini menetapkan Perda Kabupaten/Kota yang memilih Desa atau Desa Adat. Secara filosofis, semangat UU No. 6 Tahun 2014 menerapkan amanat konstitusi, yaitu pengaturan kesatuan masyarakat hukum adat sesuai dengan ketentuan Pasal 18B (2) UUD 1945 yang menegaskan Negara mengakui dan menghormati kesatuan-kesatuan masyarakat hukum adat beserta hak-hak tradisionalnya sepanjang masih hidup dan sesuai dengan perkembangan masyarakat dan prinsip Negara Kesatuan Republik Indonesia, yang diatur dalam undang-undang. Menurut Ida Bagus Geger ${ }^{35}$ bahwa secara filosofis inti politik pengakuan (rekognition) adalah tidak mematikan yang hidup dan tidak menghidupkan yang mati.

Dalam perspektif sosiologis, Tipologi Desa (dinas), Desa Adat dan Kelurahan di Badung yang saling seluk sebagai berikut: (a) Satu desa adat, dengan satu desa dinas (Kapal); (b) Satu desa adat terdiri dari beberapa desa dinas di dalam satu kecamatan (desa adat abiansemal); (c) Satu desa adat terdiri dari beberapa desa dinas diluar kecamatan (Desa adat Perang, Sempidi); (d) Satu Desa Adat terdiri dari beberapa desa dinas diluar Kabupaten Badung ( Kerobokan dan Mengwi); (e) 
Satu desa Adat terdiri dari satu banjar (Tinggan, Sogsogan); (f) Satu desa dinas terdiri dari beberapa desa adat dalam satu kecamatan (Munggu, Petang); (g) Satu desa dinas terdiri dari beberapa desa adat diluar kecamatan (Penarungan); (h) Satu desa dinas/ kelurahan dimana satu banjarnya ber-desa adat di beberapa Desa Adat diluar Kelurahan (Banjar Cenggiling Kelurahan Jimbaran); (i) Satu Kelurahan salah satu banjarnya ber-desa adat diluar Kabupaten Badung (Banjar Abianbase Kelurahan Kuta).

Eksistensi desa adat di Bali beda dengan desa adat diluar bali karena memiliki multi dimensi sebagai penjabaran dari ajaran Agama Hindu, merupakan unsur kebudayaan Bali, bersifat otonom, dibentuk oleh warga desa adat, menyelenggarakan fungsi pemerintahan komunitas adat dalam konsep Tri Hita Karana (Dharma Agama). Eksistensi Desa (dinas) sebagai bagian dari struktur pemerintahan negara, dibentuk pemerintah, menyelenggarakan fungsi pemerintahan (Dharma Negara). Jadi, Keberadaannya bukan dualisme, tetapi merupakan dualitas (bersinergi untuk saling mendukung dan menguatkan, bukan rivalitas) karena mimiliki fungsi masing-masing yang jelas berbeda. ${ }^{36}$

Hal senada disampaikan Majelis Utama Desa Pakraman (MUDP) Bali ${ }^{37}$ bahwa Bali sudah satu abad berada dalam titik equilibrium (harmonis) dengan dua desa yakni Desa Adat (Pakraman dan Desa Dinas, tanpa tumpang tindih karena tupoksi masing-masing sudah jelas. Desa Adat fokus pada urusan internal (adat), sedangkan Desa Dinas fokus pada urusan dinas (administrasi). Karena itu, usulan utama supaya Bali dapat dikhususkan dengan dua desa, sebagaimana sudah berlangsung dan terbukti berjalan harmonis selama ini.

\section{Dilema Pilihan "Desa Adat (Pakraman)" vs "Desa Dinas"}

Harapan penguatan bagi keberadaan Masyarakat Hukum Adat tercantum dalam Pasal 96 UU No. 6 tahun 2014 tentang Desa menegaskan bahwa Pemerintah dan Pemerintah Daerah Provinsi/ Kabupaten/Kota melakukan penataan kesatuan masyarakat hukum adat dan ditetapkan menjadi Desa Adat. Dalam Pasal 116 Ayat (2) dan (3) Ketentuan Peralihan mengatur bahwa, "Pemerintah Daerah Kabupaten/Kota menetapkan Peraturan Daerah tentang penetapan Desa dan Desa Adat di wilayahnya", Masih Pasal yang sama Ayat (3) yakni, "Penetapan Desa dan Desa Adat sebagaimana dimaksud pada ayat (2) paling lama 1 (satu) tahun sejak Undang-Undang ini diundangkan"

Penerapan Pasal 6 UU No. 6 tahun 2014 di Bali mengantarkan pada posisi "dilema sebuah pilihan" antara desa adat dan desa dinas yang harus didaftarkan untuk mendapatkan pengakuan sebagai desa adat versi pemerintah sehingga menjadi subjek hukum. ${ }^{38}$ Sebagai subjek hukum memiliki implikasi pada kewenangan memperoleh dana yang bersumber dari Anggaran Pendapatan dan Belanja Negara (APBN). Guna menentukan pilihan jawaban yang objekif, peneliti melakukan wawancara berbagai pihak.

Hasil penelitian cukup menarik, dapat dideskripsikan bahwa keinginan dari Ketua Adat (Bendesa) ${ }^{39}$ lebih baik Desa Adat yang didaftarkan, sementara keinginan Kepala Desa Dinas (Perbekel) ${ }^{40}$ Desa Dinas saja yang didaftarkan dan pendapat dari tokoh masyarakat $\mathrm{Bali}^{41}$ lebih baik dualisme desa

36 Wawancara dengan Bapak Wayan P. Windia, Guru Besar Hukum Adat Bali Fakultas Hukum Universitas Udayana pada hari Rabu 27 Mei 2015 bertempat di Bali Shanti Lembaga Penelitian dan Pengabdian Masyarakat (LPPM) Universitas Udayana. Beliau menyarankan seyogyanya Bali dikecualikan keharusan memilih salah satu jenis desa sebagaimana Ketentuan UU No. 6 Tahun 2014 yang justru membuat resah masyarakat Bali yang sampai saat ini hidup harmonis.

37 Majelis Utama Desa Pakraman (MUDP) Bali, "Desa Adat dalam UU Desa", Makalah, Redite Kliwon, Sungsang, 11 Mei 2014 , Bali, hlm. 9.

38 Pasal 98 Undang-Undang Nomor 6 Tahun 2014 tentang Desa Desa (Lembaran Negara Republik Indonesia Tahun 2014 Nomor 7, Tambahan Lembaran Negara Republik Indonesia Nomor 5495).

39 Wawancara dengan Bapak I Nyoman Juni Antara, S.Pd. selaku Bendesa Adat Desa Pakraman Adeng, Banjar Dinar Adeng, Desa Tegaljadi, Kecamatan Marga, Kabupaten Tabanan pada hari Selasa 26 Mei 2015.

40 Wawancara dengan Bapak I Wayan Kardana, selaku Perbekel Desa Luwus, Kecamatan Mengwi, Kabupaten Badung, pada hari Selasa 26 Mei 2015.

41 Wawancara dengan Bapak I Ketut Widia sebagai Tokoh Masyarakat Adat Bali pada hari Selasa 26 Mei 2015 . Beliau berpendapat UU No. 6 Tahun 2014 tidak cocok bagi masyarakat Bali karena keharusan memilih salah satu desa. Padahal dengan model yang sekarang ini, desa adat dan desa dinas berjalan harmonis bagaikan pasangan suami istri. Kalau salah satu yang diaftarkan (dimenangkan) justru akan menyulut konflik diantara keduanya. 
adat dan desa dinas dipertahankan dengan model sistem pemerintahan desa di Bali yang telah berjalan dengan baik. Ketika objek wawancara diperluas, ternyata mayoritas menghendaki supaya sistem dualisme desa yang ada sekarang dipertahankan.

Tabel 2. Implikasi Pilihan Salah Satu Desa yang Didaftarkan ${ }^{42}$

\begin{tabular}{|c|c|}
\hline Memakai Desa Adat (Pakraman) & Memakai Desa Dinas \\
\hline $\begin{array}{l}\text { - Desa Adat diakui sebagai subjek hukum, } \\
\text { dengan salah satu implikasi pada kewenangan } \\
\text { memperoleh dana yang bersumber dari APBN } \\
\text { (Pasal 98). } \\
\text { - Bendesa dan Perangkat Desa Adat mendapat } \\
\text { penghasilan tetap (Pasal 66). } \\
\text { - Segala bentuk perizinan yang terkait dengan } \\
\text { wilayah desa adat menjadi kewenangan penuh } \\
\text { desa adat. } \\
\text { - Merubah UU No. } 69 \text { Tahun 1958 tentang } \\
\text { Pembentukan Daerah-Daerah Tingkat II dalam } \\
\text { Wilayah Daerah-Daerah Tingkat I Bali, NTB } \\
\text { dan NTT serta UU tentang Pembentukan Kota } \\
\text { Denpasar. } \\
\text { - Masuknya DesaAdatdalam strukturpemerintahan } \\
\text { NKRI, menghilangkan independensi dan keaslian } \\
\text { Desa Adat, karena ketentuan tentang Desa juga } \\
\text { berlaku untuk Desa Adat. } \\
\text { - Sifat sakral desa adat (multi dimensi dengan } \\
\text { konsep "tri hita karana") berubah menjadi } \\
\text { sifat sekuler, profan, dan terbuka, tidak boleh } \\
\text { diskriminasi. } \\
\text { - Terjadi in-efisiensi dan efektifitas pemerintahan } \\
\text { desa (untuk desa adat dengan luas wilayah kecil } \\
\text { dengan KK yang sedikit). } \\
\text { - Penetapan Desa Adat dalam kontek untuk menata } \\
\text { kembali status Desa menjadi Desa atau Desa } \\
\text { Adat dengan ketentuan tidak boleh menambah } \\
\text { jumlah Desa yang ada (Pasal 116 ayat (2) UU } \\
\text { Desa), sehingga akan muncul masalah besar } \\
\text { (konflik) terkait dengan penggabungan Desa } \\
\text { Adat, mengingat di Badung terdapat } 122 \text { Desa } \\
\text { Adat untuk ditetapkan menjadi sebanyak } 62 \\
\text { (sebanyak Desa Dinas/ Kelurahan). }\end{array}$ & $\begin{array}{l}\text { - Desa adat semakin terpinggirkan, padahal desa } \\
\text { adat sebagai pemilik dan pemelihara adat, budaya, } \\
\text { nilai yang menjadi keunggulan komparatif } \\
\text { maupun kompetitif Bali. } \\
\text { - Desa adat Pakraman hanya menjadi sub Desa, } \\
\text { sebagai Lembaga Adat Desa, mitra pemerintah } \\
\text { desa dan lembaga desa lainnya dalam } \\
\text { meberdayakan masyarakat desa. } \\
\text { - Desa Adat belum diakui sebagai subjek hukum } \\
\text { namun keberadaan Desa Adat tidak akan hilang } \\
\text { karena dijamin oleh Pasal 18B ayat (2) UUD 1945 } \\
\text { termasuk sifat independensi dan keasliannya. } \\
\text { - Penyelenggaraan Pemerintahan lebih efektif } \\
\text { karena terjadi pemisahan tugas dan fungsi } \\
\text { (Dharma Negara oleh Desa (dinas), Dharma } \\
\text { Agama oleh Desa Adat). } \\
\text { - Desa Adat tidak masuk dalam struktur } \\
\text { pemerintahan NKRI, tetapi sebagai mitra } \\
\text { dalam memberdayakan, melestarikan dan } \\
\text { mengembangkan adat istiadat masyarakat Desa. } \\
\text { - Desa Adat tidak bisa mengakses anggaran Pusat } \\
\text { secara langsung, tetapi tetap bisa mendapatkan } \\
\text { anggaran dari pemerintah daerah dan dapat } \\
\text { diperkuat dengan Perda. } \\
\text { - Bisa mengakomodir krama non-Hindu (Desa } \\
\text { Dinas bisa mengakomodir multikultur). } \\
\text { - Memungkinkan penataan Desa (pembentukan, } \\
\text { penggabungan, pemekaran, penghapusan desa), } \\
\text { karena tidak berkaitan kewilayahan dalam } \\
\text { konteks Desa Adat (kahyangan tiga, setra). }\end{array}$ \\
\hline
\end{tabular}

Sebenarnya, polemik memilih desa adat atau desa dinas telah muncul di era reformasi. Berlakunya UU No. 22 Tahun 1999 menimbulkan wacana yang sangat intensif dikalangan masyarakat
Bali mengenai kedudukan desa pakraman. Inti dari wacana yang berkembang adalah munculnya tiga alternatif mengenai model desa di Bali. ${ }^{43}$ Pertama, dilakukan penyatuan dua bentuk desa

\footnotetext{
42 Disarikan dari hasil wawancara dengan Bapak Ida Bagus Geger dari Bagian Hukum Pemerintah Kabupaten Badung Provinsi Bali pada hari Selasa 26 Mei 2015 dan makalah MUDP Bali, Op.cit., hlm. 20-25.

43 Tim Peneliti Pusat Studi Hukum Adat Univeristas Udayana, 2001, Kedudukan Desa Adat dalam Penyelenggaraan Pemerintahan Desa Setelah Berlakunya UU No. 22 Tahun 1999 di Kabupaten Gianyar, Laporan Penelitian, Kerjasama antara Bappeda Kabupaten Gianyar dan Lembaga Penelitian Universitas Udayana, Denpasar, hlm. 50-51.
} 
pakraman dan desa dinas) dengan menetapkan desa pakraman sebagai desa menurut Undang-undang Nomor 22 Tahun 1999. Alasannya, desa yang dimaksud UU No. 22 Tahun 1999 adalah kesatuan masyarakathukumadat, dalam hal ini desa pakraman. Kedua, Model yang ditawarkan adalah desa dinas yang ditetapkan sebagai desa menurut undangundang yang keberadaannya tetap berdampingan dengan desa pakraman. Dengan demikian, kondisi yang telah ada (dualisme desa) tetap dipertahankan. Ketiga, dikembalikannya keperbekelan sebagai model desa yang melaksanakan fungsi administratif disamping desa pakraman yang tetap melaksanakan fungsi-fungsi adat dan agama.

Dalam perkembangan selanjutnya, Pemerintah Propinsi Bali mengeluarkan Peraturan Daerah Provinsi Bali Nomor 3 Tahun 2001 tentang Desa Pakraman menggantikan Peraturan Daerah Nomor 06 Tahun $1986 .{ }^{44}$ Peraturan Daerah Nomor 3 Tahun 2001 ini sendiri telah diubah dengan Peraturan Daerah Nomor 3 Tahun 2003, tetapi perubahannya tidak begitu berarti karena hanya menghapuskan satu ayat dalam pasal yang berkaitan dengan pembebasan pajak tanah desa pakraman. Dengan pengertian yang tetap sama, berdasarkan peraturan daerah yang baru ini istilah desa adat diganti dengan istilah desa pakraman. ${ }^{45}$

Dalam realita, pergantianUUNo5 Tahun 1979 dengan UU No 22 Tahun 1999 kemudian diganti UU No. 32 Tahun 2004 tentang Pemerintahan Daerah dan pergantian Peraturan Daerah Nomor 6 Tahun 1986 dengan Peraturan Daerah Nomor 3 Tahun 2001 tidak membawa perubahan mengenai posisi desa pakraman dalam hubungannya dengan pemerintah (Pemerintahan Desa ataupun Pemerintah Daerah). Dualisme desa tetap dipertahankan ${ }^{46}$ yang berarti pemerintahan desa tetap berlaku, desa dinas dan desa adat (pakraman) tetap eksis dengan fungsinya masing-masing. Eksistensi masing-masing bentuk desa tersebut secara yuridis maupun sosiologis tetap dipertahankan. Bahkan pasca UU No. 6 Tahun 2014 yang menghendaki memilih salah satu jenis desa, berdasarkan analisis hasil penelitian sebagain besar masih menghendaki berjalannya dualisme desa di Bali yakni adanya desa pakraman berdampingan dengan desa dinas.

\section{Kesimpulan}

Berdasarkan hasil penelitian dan pembahasan di atas, maka sebagai penutup dari penelitian ini dapat ditarik suatu kesimpulan bahwa keberlakuan UU No. 6 Tahun 2014 tentang desa di Bali dapat dikaji dari aspek filosofis, yuridis dan sosiologis. Dari perspektif filosofis bahwa Negara Kesatuan Republik Indonesia tetap memberikan pengakuan (recognition) dan jaminan terhadap eksistensi kesatuan masyarakat hukum adat beserta hak tradisionalnya. Perspektif yuridis, lahirnya UU No. 6 Tahun 2014 merupakan derivasi amanat Konstitusi Pasal 18B ayat (2) UUD 1945 mengenai pengakuan dan penghormatan terhadap kesatuankesatuan masyarakat hukum adat beserta hak-hak tradisionalnya termasuk di Bali dengan yakni Desa Adat (Pakraman).

Namun demikian, terdapat permasalahan konflik norma (conflict of norm) Pasal 6 dengan Penjelasan Pasal 6 UU No. 6 Tahun 2014 mengenai ketidakkonsistenan keharusan memilih salah satu jenis desa (desa adat atau desa dinas). Padahal, secara sosiologis di Bali sejak berada-abad hingga sekarang terdapat sistem pemerintahan desa bersifat ganda yang unik (dualisme), antara desa adat/pakraman (Dharma Agama) dan desa dinas (Dharma Negara) yang berjalan equilibrium secara harmonis sesuai tupoksi masing-masing.

Dalam perspektif sosiologi hukum, UU No. 6 Tahun 2014 tidak berlaku efektif di Bali, karena sebagian besar masyarakat yang dapat diwakili oleh akademisi, tokoh masyarakat, Perbekel maupun Bendesa menyatakan ketentuan Pasal 6 UU No.

44 I Wayan Gede Suacana, 2013, Transformasi Demokrasi dan Otonomi Desa, Revka Petra Media, Surabaya, hlm. 51.

45 Tjok Istri Putra Astiti, 2010, Desa Adat, Menggugat dan Digugat, Udayana University Press, Denpasar Bali, hlm. 2.

46 Istilah lainnya yakni keduaragaman pemerintahan desa. Tjokorda Raka Dherana, 1995, Desa Adat dan Awig-Awig dalam Struktur Pemerintahan Bali, Upada Sastra, Denpasar, hlm. 147. 
6 Tahun 2014 yang mengharuskan memilih salah satu jenis desa tidak cocok diterapkan di Bali. Tak mengeherankan, jika Majelis Utama Desa Pakraman (MUDP) mengusulkan supaya Bali dapat dikecualikan dengan dua desa, yakni Desa Adat dan Desa Dinas sebagaimana sudah berlangsung dan terbukti berjalan harmonis selama ini.

\section{DAFTAR PUSTAKA}

\section{A. Buku}

Ali, Achmad, 1998, Menjelajahi Kajian Empiris terhdap Hukum, Yasrif Watampone, Jakarta.

Astiti, Tjok Istri Putra, 2010, Desa Adat, Menggugat dan Digugat, Udayana University Press, Denpasar.

Bzn, B. Ter Haar, 1979, Asas-Asas dan Susunan Hukum Adat (Terj. K. Ng. Soebakti Poesponoto), Pradnya Paramita, Jakarta.

Creswell, John W., 2009, Research Design: Qualitative, Quantitative and Mixed Methods Approaches, Second Edition, Sage Publication Inc. California, USA.

Dewan Perwakilan Daerah Republik Indonesia, 2009, Naskah Akademik Rancangan Undangundang tentang Perlindungan Masyarakat Adat, Dewan Perwakilan Daerah Republik Indonesia, Jakarta.

Dewata, Mukti Fajar Nur dan Achmad Yulianto, 2010, Dualisme Penelitian Hukum Normatif dan Empiris, Pustaka Pelajar, Yogyakarta.

Dherana, Tjokorda Raka, 1995, Desa Adat dan Awig-Awig dalam Struktur Pemerintahan Bali, Upada Sastra, Denpasar.

Hamidi, Jazim, 2011, Hermeneutika Hukum: Sejarah, Filasafat dan Metode Tafsir, UB Press, Malang.

Irianto, Sulistyowati dan Shidarta, 2009, Metode Penelitian Hukum: Konstelasi dan Refleksi, Yayasan Obor Indonesia, Jakarta.

Manan, Bagir, 2001, Menyongsong Fajar Otonomi Daerah, Pusat Studi Hukum Fakultas Hukum UII, Yogyakarta.

Mertokusumo, Sudikno, 2005, Mengenal Hukum (Suatu Pengantar), Edisi Kelima Cetakan Kedua, Liberty, Yogyakarta.

Moleong, Lexy J., 2005, Metodologi Penelitian
Kualitatif, Remaja Rosdakarya, Bandung.

Neuman, William L., 2006, Social Research Methods, Qualitative and Quantitative Approaches, Sixth Edition, Pearson, USA.

Parimartha, I Gde, 2013, Silang Pandang Desa Adat dan Desa Dinas di Bali, Udayana University Press, Bali.

Rahardjo, Satjipto, 2010, Sosiologi Hukum: Perkembangan Metode dan Pilihan Masalah, Genta Publishing, Yogyakarta.

Soekanto, Soerjono, 1986, Pengantar Penelitian Hukum, Penerbit Universitas Indonesia (UI Press), Jakarta.

Soekanto, Soerjono, 2010, Hukum Adat Indonesia, Raja Grafindo Persada, Jakarta.

Soepomo, 2003, Bab-Bab tentang Hukum Adat, Pradnya Paramita, Jakarta.

Suacana, I Wayan Gede, 2013, Transformasi Demokrasi dan Otonomi Desa, Revka Petra Media, Surabaya.

Sudjito, 2014, Ilmu Hukum Holistik: Studi untuk Memahami Kompleksitas dan Pengaturan Pengelolaan Irigasi, Gadjah Mada University Press, Yogyakarta.

Sumardjono, Maria S.W., 2006, Bahan Kuliah Metodologi Penelitian Hukum, Universitas Gadjah Mada, Yogyakarta.

Sunggono, Bambang, 2006, Metodologi Penelitian Hukum, Raja Grafindo Persada, Jakarta.

Syafrudin, H. Ateng dan Na'a, Suprin, 2010, Republik Desa: Pergulatan Hukum Tradisional dan Hukum Modern dalam Desain Otonomi Desa, Alumni, Bandung.

Utsman, Sabian, 2010, Dasar-Dasar Sosiologi Hukum: Dilengkapi Proposal Penelitian Hukum (Legal Research), Pustaka Pelajar, Yogyakarta. 
Windia, Wayan P, 2013, Hukum Adat Bali dalam Tanya Jawab, Udayana University Press, Denpasar Bali.

\section{B. Artikel Jurnal}

Musakkir, "Kajian Sosiologi Hukum terhadap Penerapan Prinsip Keadilan Restoratif dalam Penyelesaian Perkara Pidana", Jurnal Ilmu Hukum Amanna Gappa, Vol. 19, No. 3, September 2011.

Sulastriyono, "Kajian Pembangunan Hukum Sumber Daya Air Sungai dalam Pespektif Sosiologi Hukum", Mimbar Hukum, Vol. 20, No. 1, Februari 2008.

\section{Hasil Penelitian/Tugas Akhir}

Atmaja, Gede Marhaendra Wija, 2012, Politik Pluralisme Hukum dalam Pengakuan Kesatuan Masyarakat Hukum Adat dengan Peraturan Daerah, Disertasi, Program Doktor Ilmu Hukum Universitas Brawijaya, Malang.

Subawa, I Made, 2003, Implikasi Yuridis Pengalihan Kekuasaan Membentuk Undang-Undang terhadap Sistem Ketatanegaraan Republik Indonesia Pasca Perubahan Undang-Undang Dasar 1945, Disertasi, Program Pascasarjana Universitas Airlangga, Surabaya.

Sudantra, I Ketut, 2007, Pelaksanaan Fungsi Hakim Perdamaian Desa dalam Kondisi Dualisme Pemerintahan Desa di Bali, Tesis, Program Pasca Sarjana Universitas Udayana, Denpasar.

Tim Peneliti Pusat Studi Hukum Adat Universitas Udayana, 2001, Kedudukan Desa Adat dalam Penyelenggaraan Pemerintahan Desa Setelah Berlakunya UU No. 22 Tahun 1999 di Kabupaten Gianyar, Laporan Penelitian, Kerjasama Antara Bappeda Kabupaten Gianyar dan Lembaga Penelitian Universitas Udayana, Denpasar.

\section{Makalah}

Majelis Utama Desa Pakraman (MUDP) Bali, "Desa Adat dalam UU Desa”, Makalah, Redite Kliwon, Sungsang, Bali, 11 Mei 2014.

\section{E. Internet}

Dwipayana, “A.A.GN Ari dan Eko Sutoro, PokokPokok Pikiran untuk Penyempurnaan UU No. 32 Tahun 2004 Khusus Pengaturan tentang Desa", http://desentralisasi.org/ makalah/ Desa/AAGNAri Dwipayana SutoroEko_ PokokPikiranPengaturanDesa.pdf, diakses 20 April 2015.

\section{F. Peraturan Perundang-Undangan}

Undang-Undang Dasar Negara Republik Indonesia Tahun 1945.

Undang-Undang Nomor 32 Tahun 2004 tentang Pemerintahan Daerah (Lembaran Negara Republik Indonesia Tahun 2004 Nomor 125, Tambahan Lembaran Republik Indonesia Negara Nomor 4437).

Undang-Undang Nomor 12 Tahun 2011 tentang Pembentukan Peraturan Perundang-undangan (Lembaran Negara Republik Indonesia Tahun 2011 Nomor 82, Tambahan Lembaran Negara Republik Indonesia Nomor 5234).

Undang-Undang Nomor 6 Tahun 2004 tentang Desa (Lembaran Negara Republik Indonesia Tahun 2014 Nomor 7, Tambahan Lembaran Negara Republik Indonesia Nomor 5495).

Peraturan Daerah Provinsi Bali Nomor 3 Tahun 2001 tentang Desa Pakraman (Lembaran Daerah Propinsi Bali Tahun 2001 Nomor 29, Tambahan Lembaran Daerah Provinsi Bali Nomor 3).

Peraturan Daerah Provinsi Bali Nomor 3 Tahun 2003 Tentang Perubahan atas Peraturan Daerah Propinsi Bali Nomor 3 Tahun 2001 Tentang Desa Pakraman (Lembaran Daerah Propinsi Bali Tahun 2003 Nomor 11, Tambahan Lembaran Daerah Provinsi Bali Nomor 3). 